\title{
Characterization of Hydration Behaviour and Modeling of Film Formulation
}

\author{
Arunima Pramanik, ${ }^{1}$ Rudra Narayan Sahoo, ${ }^{1,2}$ Souvik Nandi, ${ }^{1}$ \\ Ashirbad Nanda ${ }^{1}$ and Subrata Mallick ${ }^{1, *}$ \\ ${ }^{1}$ Department of Pharmaceutics, School of Pharmaceutical Sciences, Siksha 'O' Anusandhan (Deemed to be University), \\ Bhubaneswar 751003, Odisha, India. \\ ${ }^{2}$ Centurion University of Technology and Management, Odisha, India. \\ *Corresponding author: E-mail: profsmallick@gmail.com \\ (Telephone: +91-674-2386209; fax: +91-674 2386271
}

Received: 07-26-2020

\begin{abstract}
Hydration behavior of hydrogel-based polymeric film possesses great importance in mucosal drug delivery. Modified Lag phase sigmoid model was used for the investigation of hydration of the film. Kaolin incorporated HPMC K100LVCR $\left(\mathrm{H}_{\mathrm{L}}\right)$ and $\mathrm{K} 100 \mathrm{M}\left(\mathrm{H}_{\mathrm{H}}\right)$ films containing dexamethasone as a model drug have been prepared for studying swelling kinetics. Swelling of $\mathrm{H}_{\mathrm{L}}$ and $\mathrm{H}_{\mathrm{H}}$ films was decreased with the gradual increase of kaolin content and $\mathrm{H}_{\mathrm{H}}$ of higher viscosity has shown higher value than $\mathrm{H}_{\mathrm{L}}$ matrix. Kaolin also inhibited the film erosion process. Mathematically modified lag phase sigmoid model demonstrated similarity of the predicted swelling content with the observed value. High $\mathrm{R}^{2}$ and small RMSE value confirmed the successful fitting of the modified lag phase sigmoid model to the experimental data of swelling content. $\tau$ value similar to the observed one was obtained. This modified model could be reliable enough for estimating hydration process in food grains, food packaging films etc.
\end{abstract}

Keywords: Hydration phenomenon; water diffusion; swelling kinetic model; modified lag phase.

\section{Introduction}

Swelling behavior of polymer films possesses a significant importance in hydrogel-based transmucosal drug delivery systems and diverse application in biomolecular electronics and sensors, wound dressings, adsorption of chemical materials and contact lenses. ${ }^{1,2}$ Matrix film of hydrophilic polymer is susceptible to environmental moisture and water due to the presence of hydrophilic groups in the macromolecule chains. ${ }^{3}$ Swelling of polymer network is affected by the cross-linking degree of polymer, solvent-polymer compatibility and polymer nature. ${ }^{4}$ In the process of swelling, the solvent molecules get in contact with the polymer and diffuse into the polymer materials. Diffusion of solvent molecules into the polymer network, expansion of network, and relaxation of polymer chain are the three steps of dynamic hydration process. ${ }^{5}$ Thus swelling is responsible for the polymer chain relaxation and facilitates the patterned release of drug. Swelling develops bioadhesion through the intimate contact between polymer and mucosal tissue due to the entanglement of poly- mer and mucin chains of mucosal membrane lining. ${ }^{6}$ For transmucosal drug delivery amlodipine, budesonide, diclofenac film formulations were developed in our laboratory wherein dynamic hydration process has been described. ${ }^{6-8}$ The mucoadhesion between the mucus layer and the natural and synthetic polymers covered the mucosal epithelial surface. Further, the controlled drug release is affected by the interaction capability of polymer with mucus layer. ${ }^{9}$ Swelling gets much attention as an important mechanism of controlled drug delivery system. ${ }^{10,11}$ For hydrogel film, the dynamic process of solvent penetration can be interpreted from swelling. Based on this knowledge, the drug release pattern can be adjusted by modifying the swelling of polymer matrix. ${ }^{5}$

The incorporation of clay minerals into the polymer matrix reduces the strain of polymer matrix due to their intercalation properties ${ }^{12}$ and increments significant property. ${ }^{13}$ Silicate clay, such as montmorrilonite, has been characterized for the improvement of the biodegradability and mechanical properties of polymeric film. ${ }^{14,15}$ Kaolin, a 
phyllosilicate (1:1) crystalline clay has the cation exchange capacity. ${ }^{16}$ It consists of a tetrahedral silica sheet and an alumina octahedral sheet, and the layers are bonded together with hydrogen bonds. ${ }^{17}$ Incorporation of kaolin in drug delivery design is promoted due to its characteristic features such as chemical inertness, rheological properties, high specific area, swelling capacity and sorption capacity. The effect of kaolin incorporation in the film on the quality and functionality of swelling of film could be investigated by applying the mathematical model. This type of utilization of mathematical models is almost unavailable in the literature. The water diffusion and swelling behaviour of the polymeric film was previously studied by several researchers. ${ }^{18-21}$ In literature, the kinetic model for absorbent gels swelling was constructed by Tanaka and Filmore. ${ }^{22}$ After that, Li and Tanaka ${ }^{23}$ included some new approaches regarding swelling of gel and that was implemented by $\mathrm{Chi} \mathrm{Wu}$ and Chui-Ying $Y^{2}{ }^{24}$ for the gelatin of film swelling. Hans Schott described the swelling kinetics of gelatin film using second order kinetics. ${ }^{25}$ Peleg model has been utilized to describe the swelling kinetics of acrylamide-sodium acrylate hydrogel ${ }^{26}$ and water sorption process of food packaging films as well. ${ }^{27}$ The cellulose polymer contains hydroxyl group and it is used in different fields due to their hydrophilic and hygroscopic nature. ${ }^{28}$ Hydroxypropyl methylcellulose (HPMC) contains many hydroxyl groups and is widely used in pharmaceutical industry and other fields. ${ }^{29}$ Kinetics of food grain hydration process has already been studied by several researchers earlier using lag phase sigmoid model and other kinetic models. ${ }^{30-32}$ In this study, lag phase sigmoid model and also the modified version of this model has been applied to investigate the swelling of the films. In our knowledge, no such modification of model was used to describe the swelling kinetics of any polymeric film. Mathematical modification of lag phase sigmoid model has been described as:

$$
S_{t}=\frac{S_{E}}{1+\exp (-k(t-\tau))} \quad(1)(\text { Lag phase model })
$$

Modification:

$$
\begin{aligned}
& \frac{S_{E}}{S_{t}}=1+\exp (-k(t-\tau) \\
& \frac{S_{E}}{S_{t}}-1=\exp (-k(t-\tau) \\
& \operatorname{Ln}\left(\frac{S_{E}-S_{t}}{S_{t}}\right)=k \tau-k t
\end{aligned}
$$

$S_{E}$ is the equilibrium swelling, $k\left(\mathrm{~min}^{-1}\right)$ is the swelling rate constant and $\tau$ is the time to obtain half of the swelling sat-ration (i. e. $S_{t}=S_{E} / 2$ at $t=\tau$ ). The swelling rate constant $(k)$ can be determined from the slope of $\operatorname{Ln}\left(\frac{S_{E}-S_{t}}{S_{t}}\right)$ vs. $t$ linear plot.

\section{Experimental}

\subsection{Materials}

Dexamethasone (DXM) was received as gift sample (Sigma Company). Kaolin, HPMC K100LVCR $\left(\mathrm{H}_{\mathrm{L}}\right)$ and HPMC K100M $\left(\mathrm{H}_{\mathrm{H}}\right)$, triethanolamine were purchased from Qualikems, Burgoyne, Burbidges \& co., Merck specialities Pvt Ltd (Mumbai) respectively. Ethanol was bought from MERCK (Germany).

\section{2. Preparation of Hydrogel Film}

The polymers $\left(\mathrm{H}_{\mathrm{L}}\right.$ and $\left.\mathrm{H}_{\mathrm{H}}\right)$ were swelled in distilled water overnight and stirred continuously for 24 hours at room temperature to prepare homogenous polymeric dispersion. Simultaneously, kaolin clay dispersion (10 wt. \%) was prepared separately without any treatment by dispersing kaolin clay in distilled water and stirring for $24 \mathrm{~h}$. This dispersion was centrifuged at $2500 \mathrm{rpm}$ for $15 \mathrm{~min}$ and the thin nano-dispersion layer from the upper part was separated for film formulation. It was established that this process of dispersion in distilled water may be capable of reducing the average particle size to nano size clay particle. ${ }^{33}$ Kaolin dispersion in different amount $(25,50,75$ or $100 \mathrm{mg}$ content) was gradually added into the $\mathrm{H}_{\mathrm{L}}$ or $\mathrm{H}_{\mathrm{H}}$ polymer dispersion $(800 \mathrm{mg})$ and stirred continuously for $1 \mathrm{~h}$ with a magnetic stirrer. Dexamethasone (model drug, $100 \mathrm{mg}$ ) and triethanolamine (15\% of polymer as plasticizer) were dissolved in $5 \mathrm{ml}$ of ethanol and incorporated in each polymeric kaolin dispersion with continuous stirring for $3 \mathrm{~h}$. According to solvent casting and solvent evaporation method, final dispersion into the petri dish was spread and dried in an incubator for $24 \mathrm{~h}$ at $60{ }^{\circ} \mathrm{C}$ until constant weight. The prepared films were subjected to the following characterizations. At least three repetitions of the following experiments were done and mean $\pm \mathrm{SD}$ values were calculated.

\section{3. Water Sorption Studies}

Films were accurately weighed $\left(\mathrm{W}_{1}\right)$ at room temperature $\left(30^{\circ} \mathrm{C}\right)$ and placed in desiccators containing activated silica gel. After $24 \mathrm{~h}$ films were discarded from desiccators and weighed $\left(\mathrm{W}_{2}\right)$ until constant weight achieved. Water content was estimated from the difference between initial and final weight with respect to final weight $\left(\mathrm{W}_{2}\right)$. For water sorption analysis each film was weighed $\left(\mathrm{W}_{1}\right)$ after removal from desiccators over silica gel and placed in the desiccators to maintain 65,75 , and $84 \%$ relative humidity with $100 \mathrm{ml}$ super saturated solution of sodium nitrite, sodium chloride and potassium chloride, respectively. After about $24 \mathrm{~h}$ or more films were weighed $\left(\mathrm{W}_{2}\right)$ till three resulted weights of each film were same. Moisture uptake was determined from the difference between final and initial weight with respect to initial weight $\left(\mathrm{W}_{1}\right)$ and expressed as percentage. 


\section{4. FTIR Spectroscopy}

The possible interaction between the components was interpreted from FTIR analysis. The FTIR characterization of pure drug and the film formulations $\left(\mathrm{DH}_{\mathrm{H}} \mathrm{K}_{0}\right.$, $\mathrm{DH}_{\mathrm{H}} \mathrm{K}_{1}, \mathrm{DH}_{\mathrm{H}} \mathrm{K}_{2}, \mathrm{DH}_{\mathrm{H}} \mathrm{K}_{3}$, and $\mathrm{DH}_{\mathrm{H}} \mathrm{K}_{4}$ ) was performed using JASCO FT/IR-4100 spectra. To prepare sample pellets, $\mathrm{KBr}$ pressed-disk method was used (ratio of sample to $\mathrm{KBr}$ is 1:20) and then sample pellet was placed in FTIR spectrometer. FTIR spectra were obtained in the range of 400$4000 \mathrm{~cm}^{-1}$ and at a resolution of $4 \mathrm{~cm}^{-1}$ as transmission mode by accumulating 80 scans.

\section{5. Scanning Electron Microscopy (SEM)}

SEM images were utilized to visualize the morphology of pure drug, kaolin and film formulations $\left(\mathrm{DH}_{\mathrm{L}} \mathrm{K}_{4}\right.$, and $\mathrm{DH}_{\mathrm{H}} \mathrm{K}_{4}$ ) of highest kaolin content. Samples were gold sputter-coated under argon atmosphere and placed in JEOL/EO \$CM_VERSION 1.0 Scanning Electron Microscope model no (JSM-6390) (operating at $5 \mathrm{kV}$ ) for imaging.

\section{6. Hydration and Swelling Studies}

Films were cut into small pieces and weighed $\left(W_{0}\right)$. Then the small pieces of film were immersed into each petri plate containing $25 \mathrm{ml}$ of $\mathrm{pH} 7.4$ phosphate buffer saline at room temperature. After predetermined time interval samples were taken out from the petri plate and excess buffer was soaked in filter paper. Then the final weight $\left(W_{t}\right)$ was recorded and this process was continued up to 6 h. Swelling content was calculated by using the following equation, ${ }^{34}$

$$
S=\frac{W_{t}-W_{0}}{W_{0}}
$$

$S$ is the swelling content (g water/g dry film), $W_{t}$ is the weight of film after time $t$, and $W_{0}$ is the weight of dry film.

Erosion of film can also be analyzed from swelling studies. After $6 \mathrm{~h}$ of swelling study, films were dried at $40{ }^{\circ} \mathrm{C}$ in hot air oven. Films were removed from the oven after $24 \mathrm{~h}$ and reweighed $\left(W_{e}\right)$ and erosion $(E)$ was calculated as follow,

$$
E=\frac{W_{0}-W_{e}}{W_{0}}
$$

$W_{e}$ is the weight of the eroded film after drying in oven.

Swelling of polymer involved diffusion of water and necessitated the understanding of mechanism of solvent diffusion. The swelling kinetics and diffusion of polymer structure can be explained by basic law of Peppas law. ${ }^{24}$

$$
F=\frac{S_{t}}{S_{\max }}=K t^{n}
$$

where, $F$ is the fraction of swelling content, $S_{\max } \mathrm{i}$ the maximum swelling content of the formulation, $S_{t}$ the swelling content of the formulation at any time, $K$ the gel network structure constant, and $n$ the diffusion exponential of solvent. The ' $n$ ' value of Peppas equation was utilized to determine the diffusion type. Coefficient of diffusion, an important parameter, was also evaluated from the swelling kinetics. It can be calculated for the square shape film from the following equation which was derived by re-arranging the Fick's II law.

$$
D=a^{2}\left(\frac{K}{4}\right)^{1 / n}
$$

where $D$ is the diffusion coefficient expressed in $\mathrm{cm}^{2} \mathrm{~s}^{-1}$, and " $a$ " is the side of square film in $\mathrm{cm}$.

In order to determine the swelling kinetics of films, lag phase sigmoid model was exploited in this study. The lag phase sigmoid equation has been modified to generalize the swelling kinetics study and also to compare it with the original lag phase sigmoid model.

Kaptso et al also proposed a sigmoid model and described the swelling of film. ${ }^{36}$ The equation of this sigmoid model, comprised of an exponential rate of decay term, is accounted for an initial lag phase. The model is expressed as the following equation

$$
S_{t}=\frac{S_{E}}{1+\exp (-k(t-\tau))}
$$

$S_{E}$ is the equilibrium swelling, $k\left(\mathrm{~min}^{-1}\right)$ is the swelling rate constant and $\tau$ is the time to obtain half of the swelling saturation (i. e. $S_{t}=S_{E} / 2$ at $t=\tau$ ).

\section{7. Statistical Analysis}

The model was statistically fitted with the experimental data and analyzed in Origin Pro 8.0 (OriginLab, Northampton, MA) software ${ }^{37}$ by the nonlinear regression analysis. Model fitness to the experimental data has been assessed using $R^{2}, \chi^{2}$, and root mean square error (RMSE) of statistical analysis data. $\chi^{2}$ and RMSE can be calculated as

$$
\begin{aligned}
& \chi^{2}=\frac{\sum_{i=1}^{N}\left(S_{\text {exp }, i}-S_{\text {pre }, i}\right)^{2}}{N-z} \\
& R M S E=\left[\frac{1}{N} \sum_{i=1}^{N}\left(S R_{\text {pre }, i}-S R_{\text {exp }, i}\right)^{2}\right]^{1 / 2}
\end{aligned}
$$

\section{Results and Discussion}

\section{1. Water Sorption Properties}

The moisture content and moisture uptake of DXM film composed of HPMC and kaolin were measured at 
Table 1. Water sorption properties of the film formulations.

\begin{tabular}{|c|c|c|c|c|c|}
\hline \multirow{2}{*}{ Formulation } & \multirow{2}{*}{$\begin{array}{l}\text { DXM : } \\
\text { kaolin }\end{array}$} & \multicolumn{3}{|c|}{$\%$ Water uptake at $\mathrm{RH}($ mean $\pm \mathrm{SD}, \mathrm{n}=3)$ Water content $(\%)$} & \multirow[b]{2}{*}{$($ mean $\pm S D, n=3)$} \\
\hline & & $65 \%$ & $75 \%$ & $85 \%$ & \\
\hline $\mathrm{DH}_{\mathrm{L}} \mathrm{K}_{0}$ & - & $4.50 \pm 0.02$ & $12.61 \pm 0.03$ & $21.62 \pm 0.03$ & $2.80 \pm 0.01$ \\
\hline $\mathrm{DH}_{\mathrm{L}} \mathrm{K}_{1}$ & $1: 0.25$ & $4.31 \pm 0.03$ & $12.06 \pm 0.03$ & $19.82 \pm 0.03$ & $2.58 \pm 0.01$ \\
\hline $\mathrm{DH}_{\mathrm{L}} \mathrm{K}_{2}$ & $1: 0.5$ & $3.81 \pm 0.02$ & $11.45 \pm 0.03$ & $19.08 \pm 0.02$ & $2.34 \pm 0.01$ \\
\hline $\mathrm{DH}_{\mathrm{L}} \mathrm{K}_{3}$ & $1: 0.75$ & $3.42 \pm 0.02$ & $10.28 \pm 0.03$ & $17.00 \pm 0.03$ & $2.06 \pm 0.01$ \\
\hline $\mathrm{DH}_{\mathrm{L}} \mathrm{K}_{4}$ & $1: 1$ & $3.40 \pm 0.03$ & $10.20 \pm 0.04$ & $16.57 \pm 0.03$ & $1.14 \pm 0.02$ \\
\hline $\mathrm{DH}_{\mathrm{H}} \mathrm{K}_{0}$ & - & $6.76 \pm 0.04$ & $14.28 \pm 0.08$ & $24.81 \pm 0.11$ & $3.87 \pm 0.02$ \\
\hline $\mathrm{DH}_{\mathrm{H}} \mathrm{K}_{1}$ & $1: 0.25$ & $5.81 \pm 0.05$ & $13.95 \pm 0.09$ & $22.09 \pm 0.10$ & $3.52 \pm 0.02$ \\
\hline $\mathrm{DH}_{\mathrm{H}} \mathrm{K}_{2}$ & $1: 0.5$ & $5.22 \pm 0.05$ & $13.43 \pm 0.08$ & $19.40 \pm 0.10$ & $3.22 \pm 0.01$ \\
\hline $\mathrm{DH}_{\mathrm{H}} \mathrm{K}_{3}$ & $1: 0.75$ & $4.65 \pm 0.05$ & $12.79 \pm 0.06$ & $19.76 \pm 0.06$ & $2.68 \pm 0.02$ \\
\hline $\mathrm{DH}_{\mathrm{H}} \mathrm{K}_{4}$ & $1: 1$ & $4.57 \pm 0.06$ & $11.76 \pm 0.07$ & $18.30 \pm 0.03$ & $2.40 \pm 0.02$ \\
\hline
\end{tabular}

$25{ }^{\circ} \mathrm{C}$, and at 65,75 , and $85 \%$ relative humidity. Table 1 displays the gradual depletion of both water content and water uptake while kaolin content increases in the film. It is also seen that moisture uptake of all respective formulations is progressively increasing with increasing $\mathrm{RH}$ from 65 to $85 \%$. The highest kaolin content in the film resulted in the decreased percent moisture uptake from $4.50 \pm 0.02$ to $3.40 \pm 0.03$ and $6.76 \pm 0.04$ to $4.57 \pm 0.06$ at $65 \% \mathrm{RH}$ for $\mathrm{H}_{\mathrm{L}}$ and $\mathrm{H}_{\mathrm{H}}$ matrices respectively in comparison with the absence of kaolin film. Percent moisture content of film has also been reduced from $2.80 \pm 0.004$ to $1.14 \pm 0.02$ and from $3.87 \pm 0.02$ to $2.40 \pm 0.02$ for $\mathrm{H}_{\mathrm{L}}$ and $\mathrm{H}_{\mathrm{H}}$ matrices respectively in the presence of kaolin (1:1) compared to the kaolin free films. The observed result indicated that the water resistance of both the matrix formulations was increased when kaolin was present in the film. In presence of triethanolamine as plasticizer, fine kaolin particles in the HPMC matrix enhanced the HPMC-kaolin interactions and left less free hydroxyl groups available for water binding. Thus, increased kaolin content gradually enhanced the barrier effect for the water uptake. ${ }^{38,39}$

\section{2. FTIR}

The analysis of the chemical constituent of pharmaceutical solids has been carried out by the FTIR spectroscopy. The drug-excipient interaction nature was also confirmed from the changes in the IR spectra. The changes in drug-excipient interactions are displayed as the disappearance of existing bands and appearance of new bands in the IR spectra, and also as intensity alteration and absorption band broadening. Figure 1 shows the IR spectra of kaolin, pure DXM and formulations. The characteristic absorption peaks of DXM in IR spectra that appear at 3000-2800 $\mathrm{cm}^{-1}, 885 \mathrm{~cm}^{-1}, 1718 \mathrm{~cm}^{-1}, 1665 \mathrm{~cm}^{-1}$ and $1621 \mathrm{~cm}^{-1}$, are assigned to $\mathrm{CH}_{2}$ group, axial deformation of C-F group,

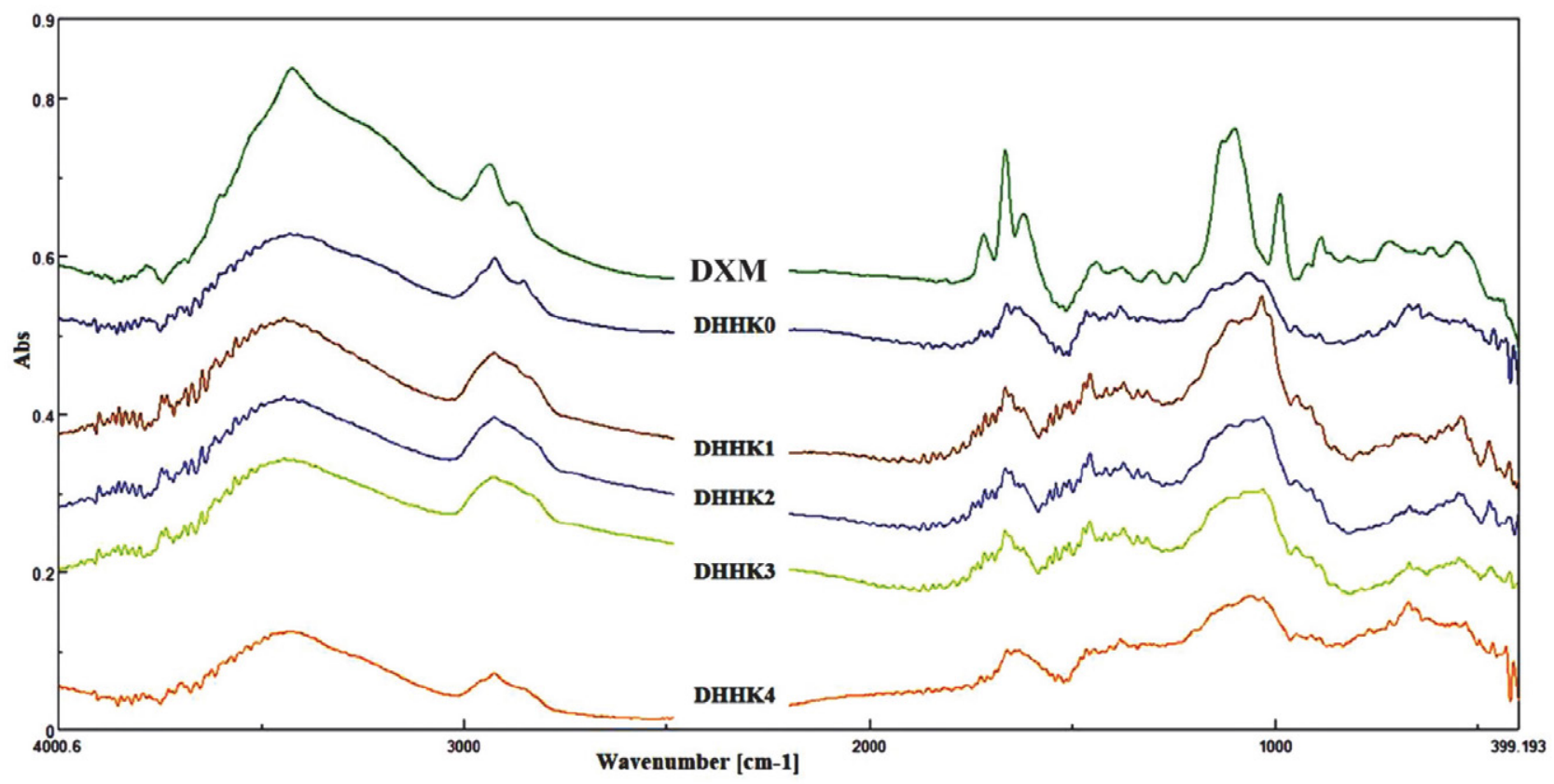

Figure 1. FTIR spectra of pure DXM and of the prepared film formulations $\left(\mathrm{DH}_{\mathrm{H}} \mathrm{K}_{0}, \mathrm{DH}_{\mathrm{H}} \mathrm{K}_{1}, \mathrm{DH}_{\mathrm{H}} \mathrm{K}_{2}, \mathrm{DH}_{\mathrm{H}} \mathrm{K}_{3}\right.$, and DH $\left.\mathrm{DH}_{4}\right)$. 
carbonyl group $(\mathrm{C}=\mathrm{O})$ of aliphatic ester and ketone,${ }^{40}$ and $\mathrm{C}=\mathrm{C}$ group, respectively. ${ }^{41}$ IR spectrum of pure kaolin demonstrated absorption peak at $1032 \mathrm{~cm}^{-1}$ with high intensity due to $\mathrm{Si}-\mathrm{O}$ stretching in kaolin. ${ }^{42}$ Kaolin contains hydroxyl groups at different position, i.e. outer hydroxyl groups $(\mathrm{OuOH}$, positioned in the upper unshared plan) and inner hydroxyl groups ( $\mathrm{InOH}$, positioned in the lower unshared plan of octahedral sheet). Kaolin spectra showed peaks at $3693,3669,3649 \mathrm{~cm}^{-1}$ and at $3619 \mathrm{~cm}^{-1}$ due to the stretching of $\mathrm{OuOH}$ and stretching of $\mathrm{InOH}$ in $\mathrm{Al}-\mathrm{OH} .^{43}$ The broadening of absorption band at $3000-2800 \mathrm{~cm}^{-1}$ appeared due to the presence of polymer in the film. The successful incorporation of DXM in films has been confirmed by the presence of the main characteristic absorption peak
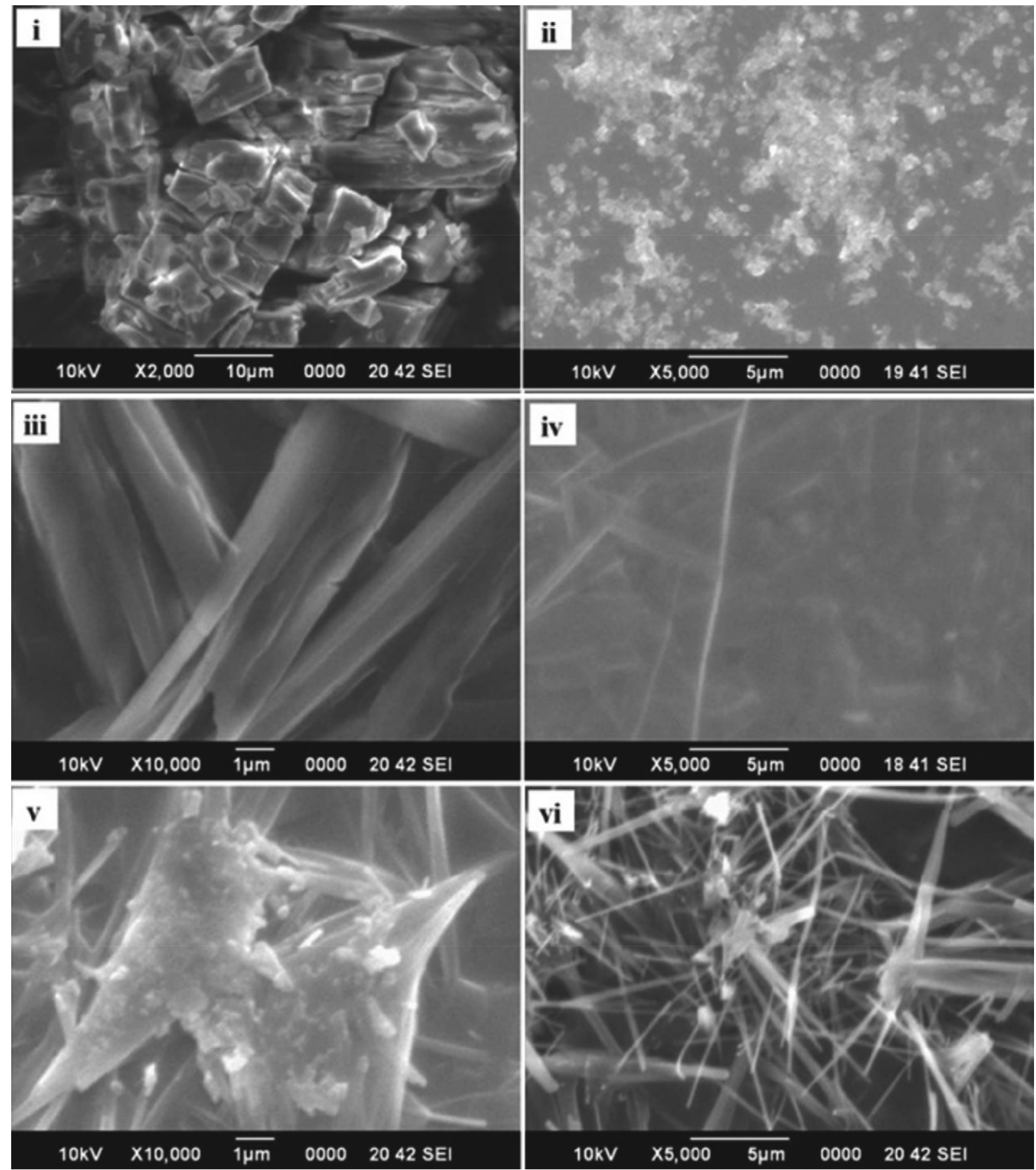

Figure 2. Scanning electron micrograph of pure DXM (magnification 2,000) (i); kaolin (magnification 5,000) (ii); films with kaolin (magnification 10,000) (iii), (magnification 5,000) (iv) of HPMC K100 LVCR; and films with kaolin (magnification 10,000) (v), (magnification 5,000) (vi) of HPMC K100 M matrices. 
at $1665 \mathrm{~cm}^{-1}$. This result suggested that the chemical properties of DXM have remained the same in the films. Interaction between DXM and kaolin in the film formulations has been confirmed by the shifting of the peak at 1032 $\mathrm{cm}^{-1}$. The formation of hydrogen bond can be concluded as a result of this band shifting. The broadening of the characteristic peak at $1032 \mathrm{~cm}^{-1}$ was observed in the wide range in IR spectra of films containing higher kaolin content. This result indicates stronger binding between DXM and kaolin with the corresponding increase of kaolin content in the films.

\section{3. Scanning Electron Microscopy}

The surface morphology of pure DXM, kaolin, and films of both HPMC K100 LVCR and HPMC K100 M matrices is demonstrated in Figure 2 by the scanning electron micrographs. The SEM images of Figure 2(i) demonstrate the geometric plate shaped microstructure of pure DXM and Figure 2(ii) that of nanosized kaolin. Figure 2(iii \& iv) and ( $v \& v i$ ) represent the SEM images of films with higher kaolin content of both $\mathrm{H}_{\mathrm{L}}$ and $\mathrm{H}_{\mathrm{H}}$ matrices, respectively. The SEM images of films with added kaolin demonstrate the distinct distribution of nano-sized kaolin particles in the film. It can also be observed that the crystalline shape of DXM has almost disappeared in the films. In the presence of triethanolamine, the growth of drug crystal in HPMC film was not adequately noticed in the SEM micrographs due to the interfacial adhesion between the polymer phases and drug. ${ }^{44}$ The crystal growth is also inhibited by HPMC in the matrix. ${ }^{45}$

\section{4. Hydration Behavior}

The biological characteristic of hydrogel-based transmucosal drug delivery system significantly depended on the swelling of polymer present. Swelling capacity and swelling content of the film formulations were investigated in phosphate buffer saline $(\mathrm{pH} 7.4)$ at the laboratory ambient conditions. Swelling process included water uptake followed by the process of erosion of polymer matrix. The change of swelling content of film of both $\mathrm{H}_{\mathrm{L}}$ and $\mathrm{H}_{\mathrm{H}}$ matrix with varied kaolin content is depicted in Figure 3 and Figure 4 respectively. Graphs display that film of $\mathrm{H}_{\mathrm{L}}$ and $\mathrm{H}_{\mathrm{H}}$ matrices exhibited maximum swelling at 60 min and 6 $\mathrm{h}$ respectively. Decreased swelling content was observed while kaolin content increased in the film. The water resistance ability of kaolin resulted in sustaining swelling of polymer-based film matrix. Water resistance ability has been improved by increasing the kaolin content and gradually sustained the swelling of the film. Water uptake, the main basis for swelling, depends on the hydrophilicity and other parameter such as morphology (macro voids), free volume, and crystal size. Hence, swelling may also be dependent on these parameters. Kaolin produced a tortuous pathway and also formed a denser cross-linking network due to its certain level of hydrophilicity. ${ }^{46,47}$ Thus kaolin had the capability of reducing the length of free pathway for water uptake into matrix, which led to sustained swelling of the film matrix.

In film formulations $\left(\mathrm{H}_{\mathrm{L}}\right.$ and $\left.\mathrm{H}_{\mathrm{H}}\right)$ swelling content was increased with the time of swelling. Higher swelling was found in the initial stage followed by a slower swelling at the later stages, known as hyperbolic form. ${ }^{25}$ The form of difference in swelling content in the graphs (between $\mathrm{H}_{\mathrm{L}}$ and $\mathrm{H}_{\mathrm{H}}$ ) is related probably to the polymer viscosity and molecular weight, because high molecular weight polymers exhibit high viscosity in the swelling stage. ${ }^{48}$ The result of swelling content demonstrated higher value for the film of HPMC K100 M matrix compared with the film of HPMC K100LVCR matrix. This result suggests that the polymer viscosity and molecular weight play a role in the process of film swelling. The water uptake process did not easily empower through higher viscosity polymer of HPMC K100 M matrix. High molecular weight polymer increased the impact resistance due to higher degree of entanglement for rupturing more polymer bonds. In a fully hydrated state polymer chain disentanglement occured when there was no polymer-polymer interactions and higher viscosity induced greater chain entanglement than lower viscosity. Praveen et al. ${ }^{49}$ also described in their report that the polymer chain disentanglement is affected by the polymer viscosity. Film of $\mathrm{H}_{\mathrm{H}}$ matrix with maximum kaolin content showed higher swelling index, which suggests decreased movement of DXM molecules from the film matrix to the medium.

Erosion of film matrix is the process that follows after swelling and proceeds slowly. In this process, drug molecules diffuse through the micropores of polymer after

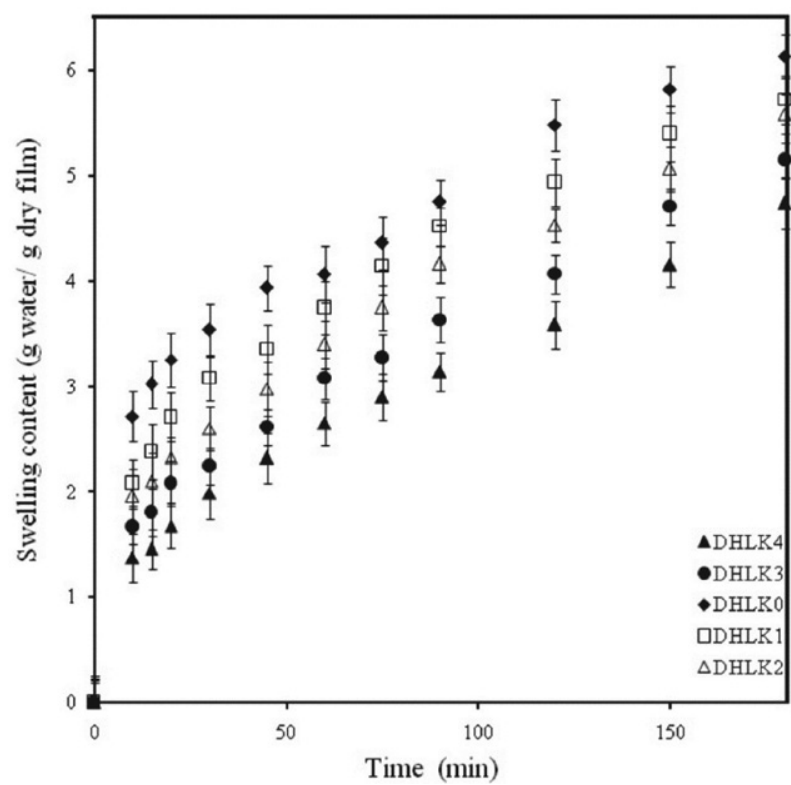

Figure 3. Swelling content of film of HPMC K100 LVCR $\left(\mathrm{H}_{\mathrm{L}}\right)$ matrix with varied kaolin content. 


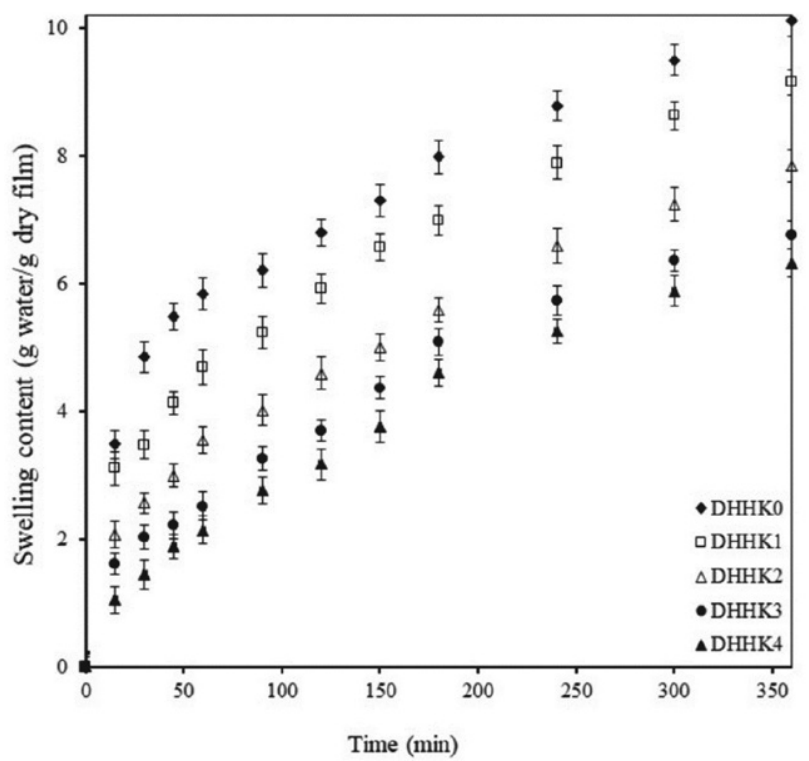

Figure 4. Swelling content of film of HPMC K100 M $\left(\mathrm{H}_{\mathrm{H}}\right)$ matrix with varied kaolin content.

water uptake of the matrix. ${ }^{6}$ After $6 \mathrm{~h}$ of the swelling study, erosion of films has been measured in $\mathrm{pH} 7.4$ phosphate buffer saline. Figure 5 shows the progressive decrease in erosion with gradually increased kaolin content in the film. Presence of kaolin in the film hinders the process of erosion of film due to the entrapment of kaolin in the HPMC matrix networks. Higher kaolin content in the film has developed relatively stronger affinity between kaolin and polymer. Thus, the film with higher kaolin content shows more resistance for erosion. More resistance to the film erosion was also seen due to greater viscosity of $\mathrm{H}_{\mathrm{H}}$ compared to $\mathrm{H}_{\mathrm{L}}$.

\section{5. Diffusion of Water}

The predicted swelling value is similar with the experimental swelling value, when the swelling kinetics of

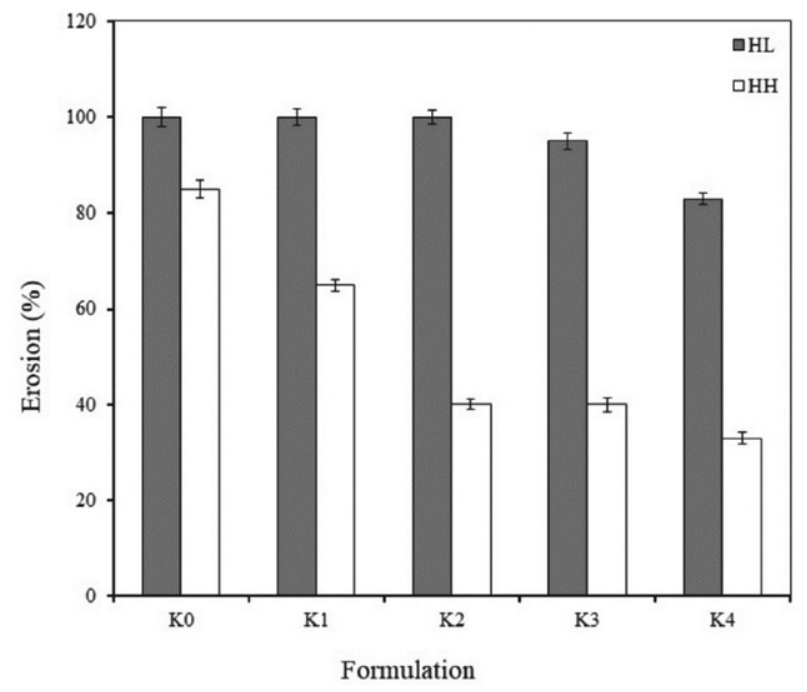

Figure 5. Erosion of film of HPMC K100 LVCR $\left(\mathrm{H}_{\mathrm{L}}\right)$ and HPMC $\mathrm{K} 100 \mathrm{M}\left(\mathrm{H}_{\mathrm{H}}\right)$ matrix with varied kaolin content.

films has been described by the Peppas model (RMSE = 0.016-0.02 for $\mathrm{H}_{\mathrm{L}}$ matrix film and 0.016-0.02 for $\mathrm{H}_{\mathrm{H}}$ matrix film). The diffusion exponential $(n), k, R^{2}$, reduced chi-square $\left(\chi^{2}\right)$ and RMSE values of all matrix films are demonstrated in Table 2. In order to investigate the water diffusion mechanism into hydrogel DXM film, Peppas equation was utilized. On the basis of the $n$ value, the diffusion type of swelling was determined. ${ }^{50}$ Fickian and non-Fickian diffusion are identified by the $n$ values of 0.5 and 1.0, respectively. The ranges of swelling exponent values of films of $\mathrm{H}_{\mathrm{L}}$ and $\mathrm{H}_{\mathrm{H}}$ matrix are $0.28-0.43$ and $0.31-$ 0.59 respectively. According to the calculated $n$ value, the diffusion mechanism of swelling of films of $\mathrm{H}_{\mathrm{L}}$ and $\mathrm{H}_{\mathrm{H}}$ matrix was Fickian and anomalous diffusion, respectively. Diffusion coefficient (D) is an important factor that describes how quickly water can diffuse through the polymeric matrix film. The results revealed that the $\mathrm{D}$ value increased with the increased kaolin content in the film

Table 2. Estimated swelling parameters of the film as per Peppas model and the diffusion coefficient of water.

\begin{tabular}{lcccccr}
\hline \multirow{2}{*}{ Formulation } & $\boldsymbol{k}$ & $\boldsymbol{n}$ & $\boldsymbol{R}^{\mathbf{2}}$ & $\boldsymbol{\chi}^{\mathbf{2}}$ & $\boldsymbol{R} \boldsymbol{M S E}$ & $\boldsymbol{D}\left(\boldsymbol{c m}^{2} \boldsymbol{s}^{-1}\right)$ \\
\hline $\mathrm{DH}_{\mathrm{L}} \mathrm{K}_{0}$ & 0.23 & 0.28 & 0.98 & $3.17 \mathrm{E}-04$ & 0.016 & $1.32^{\star} 10^{-4}$ \\
$\mathrm{DH}_{\mathrm{L}} \mathrm{K}_{1}$ & 0.16 & 0.35 & 0.99 & $8.81 \mathrm{E}-05$ & 0.008 & $4.04^{\star} 10^{-4}$ \\
$\mathrm{DH}_{\mathrm{L}} \mathrm{K}_{2}$ & 0.14 & 0.37 & 0.99 & $3.61 \mathrm{E}-04$ & 0.017 & $4.59^{\star} 10^{-4}$ \\
$\mathrm{DH}_{\mathrm{L}} \mathrm{K}_{3}$ & 0.12 & 0.39 & 0.98 & $4.93 \mathrm{E}-04$ & 0.020 & $5.54^{\star} 10^{-4}$ \\
$\mathrm{DH}_{\mathrm{L}} \mathrm{K}_{4}$ & 0.10 & 0.43 & 0.99 & $4.44 \mathrm{E}-04$ & 0.019 & $7.31^{\star} 10^{-4}$ \\
$\mathrm{DH}_{\mathrm{H}} \mathrm{K}_{0}$ & 0.16 & 0.31 & 0.98 & $3.19 \mathrm{E}-04$ & 0.016 & $1.23^{\star} 10^{-4}$ \\
$\mathrm{DH}_{\mathrm{H}} \mathrm{K}_{1}$ & 0.12 & 0.36 & 0.99 & $2.98 \mathrm{E}-04$ & 0.016 & $2.24^{\star} 10^{-4}$ \\
$\mathrm{DH}_{\mathrm{H}} \mathrm{K}_{2}$ & 0.08 & 0.43 & 0.99 & $2.76 \mathrm{E}-04$ & 0.015 & $4.12^{\star} 10^{-4}$ \\
$\mathrm{DH}_{\mathrm{H}} \mathrm{K}_{3}$ & 0.06 & 0.49 & 0.98 & 0.00101 & 0.029 & $6.30^{\star} 10^{-4}$ \\
$\mathrm{DH}_{\mathrm{H}} \mathrm{K}_{4}$ & 0.03 & 0.59 & 0.99 & $4.04 \mathrm{E}-04$ & 0.018 & $10.89^{\star} 10^{-4}$ \\
\hline & & \multicolumn{7}{c}{}
\end{tabular}


(Table 2). With the gradual increase in the kaolin content, water penetration becomes faster in both the polymers $\left(\mathrm{H}_{\mathrm{L}}\right.$ and $\left.\mathrm{H}_{\mathrm{H}}\right)$. The calculated diffusion coefficient increases from $1.32{ }^{\star} 10^{-4} \mathrm{~cm}^{2} \mathrm{~s}^{-1}$ to $7.31{ }^{\star} 10^{-4} \mathrm{~cm}^{2} \mathrm{~s}^{-1}$ for $\mathrm{H}_{\mathrm{L}}$ matrix and $1.23{ }^{\star} 10^{-4}$ to $10.89{ }^{\star} 10^{-4}$ for $\mathrm{H}_{\mathrm{H}}$ matrix.

\section{6. Evaluation of Lag Phase Model and Modified Lag Phase Model}

The fitting of lag phase sigmoid model on the swelling data of film of both matrices $\left(\mathrm{H}_{\mathrm{L}}\right.$ and $\left.\mathrm{H}_{\mathrm{H}}\right)$ is shown in Figure 6 \& Figure 7, respectively. The swelling data fitting with modified lag phase sigmoid model is depicted in Figure 8 \& Figure 9 of $\mathrm{H}_{\mathrm{L}}$ and $\mathrm{H}_{\mathrm{H}}$, respectively. The parameters $\left(R^{2}, k, \tau, S_{\text {obs.eq }}\right.$, RMSE, $\left.\chi^{2}\right)$ of this model are presented in Table 3 for all films. These parameters describe the kinetics of all films with lower RMSE and $\chi^{2}$ value and high correlation coefficient indicating appropriate fitting of model on swelling data. The time to obtain half of the swelling saturation $(\tau)$ is increased by higher kaolin content in the film. The predicted equilibrium swelling content and $\tau$ show higher value for $\mathrm{H}_{\mathrm{H}}$ compared to $\mathrm{H}_{\mathrm{L}}$ matrix film. Predicted equilibrium swelling content is similar to the experimentally obtained equilibrium moisture content. Modified lag phase sigmoid model demonstrates the increasing order of observed $\tau$ (17.6 to 105.7 and 38.4 to $283.1)$ and decreasing or almost similar order of $k$ (20.3 to 12.4 and 9.4 to 6.3) with increased kaolin content in the film of both matrices $\left(\mathrm{H}_{\mathrm{L}}\right.$ and $\mathrm{H}_{\mathrm{H}}$ matrix). Lag phase sigmoid model rate constant $(k)$ decreases with increasing kaolin content in the film of both matrices supporting the effect of kaolin on prolonged swelling of the film. Kaptso et $\mathrm{al}^{25}$ also described that the increased sigmoid model rate constant is due to increased mass transfer rate. However,

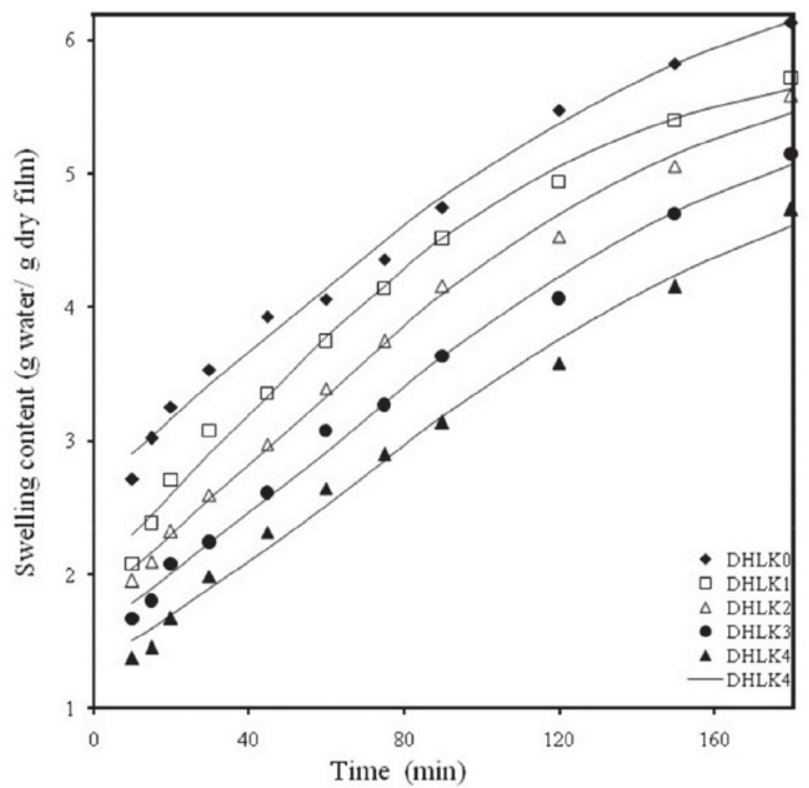

Figure 6. Fitting of the Lag phase sigmoid model of films of HPMC K100LVCR $\left(\mathrm{H}_{\mathrm{L}}\right)$ matrix with varied kaolin content.

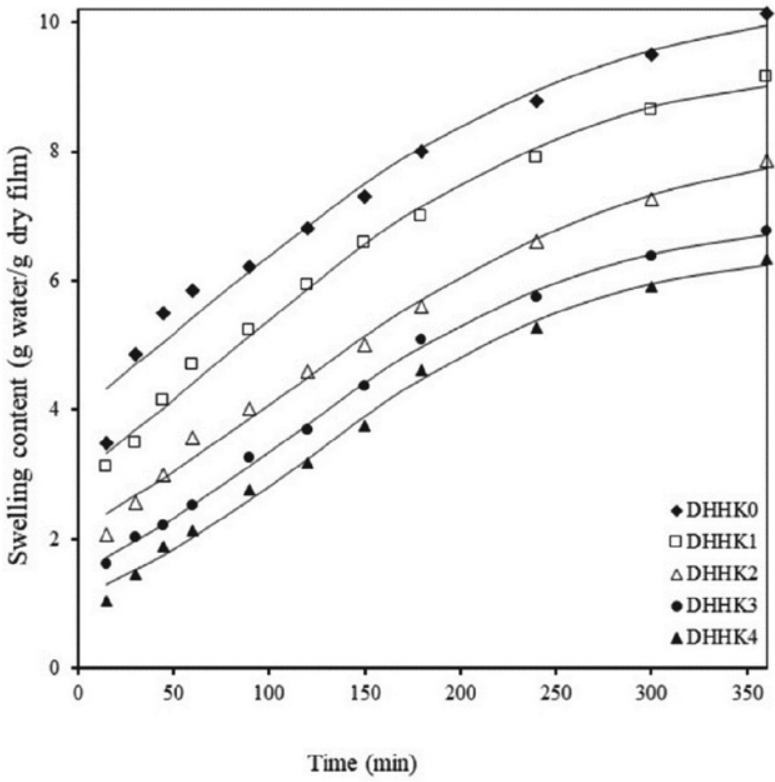

Figure 7. Fitting of the Lag phase sigmoid model of films of HPMC $\mathrm{K} 100 \mathrm{M}\left(\mathrm{H}_{\mathrm{H}}\right)$ matrix with varied kaolin swelling content.

Table 3. Estimated parameters of the modified Lag phase model.

\begin{tabular}{lccccccc}
\hline Formulation & \multicolumn{7}{c}{ Parameter of the modified lag phase model } \\
& $S_{\text {obs.eq }}$ & $\begin{array}{c}\text { Obs } \boldsymbol{\tau} \\
(\boldsymbol{m i n})\end{array}$ & $\begin{array}{c}\boldsymbol{k} \times \mathbf{1 0}^{\mathbf{3}} \\
\text { Predicted } \boldsymbol{\tau}\end{array}$ & $\boldsymbol{R}^{\mathbf{2}}$ & $\boldsymbol{R} \boldsymbol{M S E})$ & $\boldsymbol{\chi}^{\mathbf{2}}$ \\
& & 17.6 & 24.3 & 20.3 & 0.951 & 0.174 & 0.03 \\
\hline $\mathrm{mH}_{\mathrm{L}} \mathrm{K}_{0}$ & $6.32)$ & 41.6 & 16.1 & 0.984 & 0.138 & 0.01 \\
$\mathrm{DH}_{\mathrm{L}} \mathrm{K}_{1}$ & 6.38 & 37.2 & 64.3 & 14.1 & 0.996 & 0.119 & 0.01 \\
$\mathrm{DH}_{\mathrm{L}} \mathrm{K}_{2}$ & 6.70 & 55.2 & 84.5 & 13.0 & 0.999 & 0.121 & 0.01 \\
$\mathrm{DH}_{\mathrm{L}} \mathrm{K}_{3}$ & 6.75 & 80.6 & 107.1 & 12.4 & 0.998 & 0.145 & 0.01 \\
$\mathrm{DH}_{\mathrm{L}} \mathrm{K}_{4}$ & 6.77 & 105.7 & 57.7 & 9.4 & 0.964 & 0.338 & 0.03 \\
$\mathrm{DH}_{\mathrm{H}} \mathrm{K}_{0}$ & 10.62 & 38.4 & 115.4 & 7.1 & 0.994 & 0.290 & 0.02 \\
$\mathrm{DH}_{\mathrm{H}} \mathrm{K}_{1}$ & 11.02 & 103.6 & 196.2 & 6.5 & 0.999 & 0.321 & 0.02 \\
$\mathrm{DH}_{\mathrm{H}} \mathrm{K}_{2}$ & 11.14 & 173.3 & 253.1 & 6.3 & 0.995 & 0.412 & 0.04 \\
$\mathrm{DH}_{\mathrm{H}} \mathrm{K}_{3}$ & 11.33 & 219.7 & 287.3 & 6.9 & 0.989 & 0.485 & 0.06 \\
$\mathrm{DH}_{\mathrm{H}} \mathrm{K}_{4}$ & 11.70 & 283.1 & & & & & \\
\hline
\end{tabular}




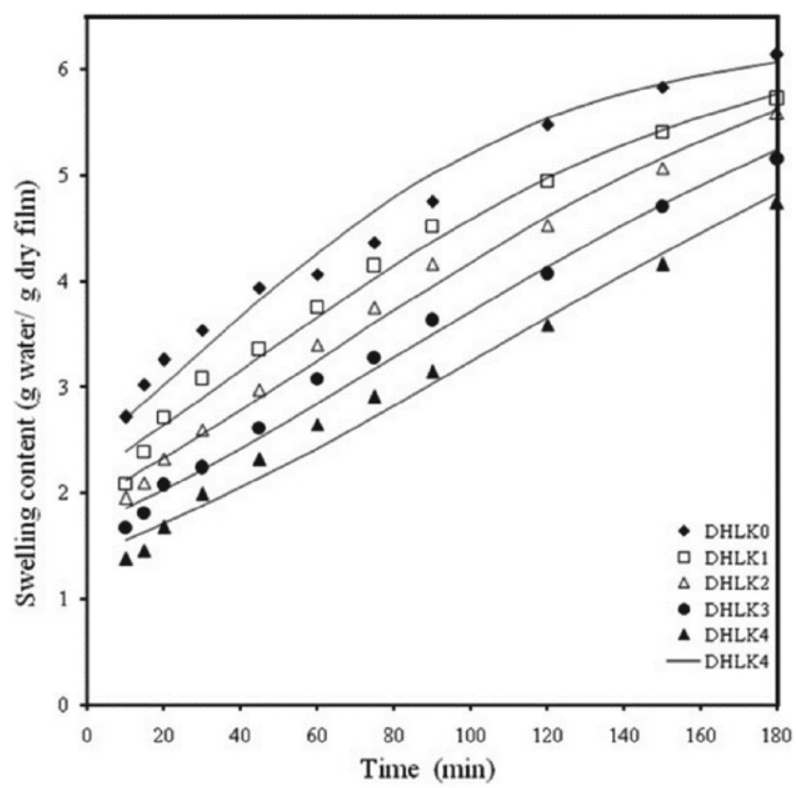

Figure 8. Fitting of the modified Lag phase sigmoid model of films of HPMC K100LVCR matrix with varied kaolin content.

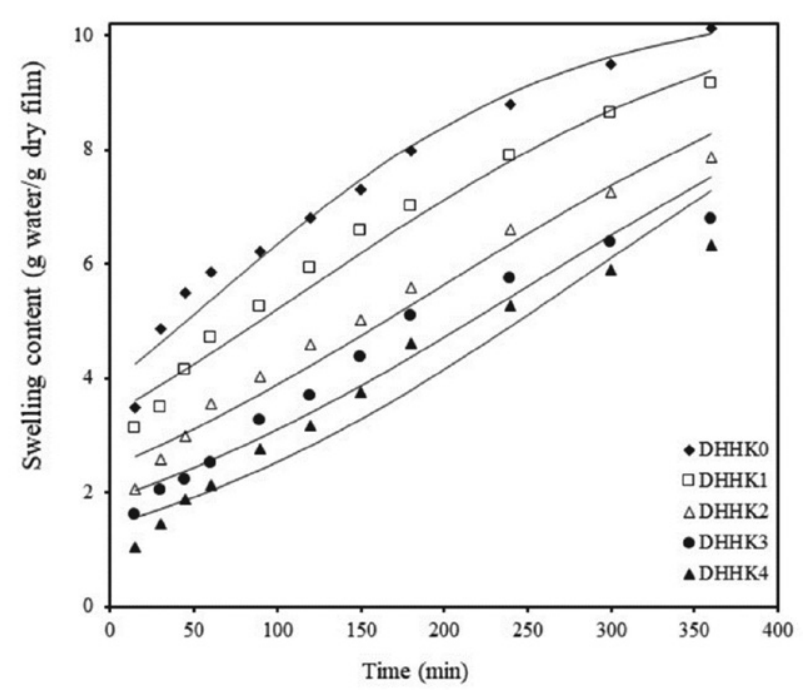

Figure 9. Fitting of the modified Lag phase sigmoid model of films of HPMC K100 M ( $\left.\mathrm{H}_{\mathrm{H}}\right)$ matrix with varied kaolin swelling content.

the predicted value of $\tau$ increased from 24.26 to 107.10 and from 57.75 to $287.29 \min$ for $\mathrm{H}_{\mathrm{L}}$ and $\mathrm{H}_{\mathrm{H}}$, respectively. Correspondingly, $k$ value decreased from 0.02 to 0.012 and from 0.009 to $0.006 \mathrm{~min}^{-1}$ for $\mathrm{H}_{\mathrm{L}}$ and $\mathrm{H}_{\mathrm{H}}$, respectively. The fitting of this model is justified by the small RMSE and high $R^{2}$ value. Hence, the proposed modified Lag phase sigmoid model may be acceptable in the hydration study.

\section{Conclusion}

Kaolin incorporated HPMC films containing dexamethasone as a model drug have been prepared for charac- terization of hydration behaviour utilizing modified lag phase model. In this study, the effect of kaolin on swelling of $\mathrm{H}_{\mathrm{L}}$ and $\mathrm{H}_{\mathrm{H}}$ hydrogel films was investigated. Gradually decreased water content and water uptake were observed with increased kaolin content in the film. Distribution of nano-sized kaolin particles in the films was noticed in the SEM images. Swelling of both the matrices $\left(\mathrm{H}_{\mathrm{L}}\right.$ and $\left.\mathrm{H}_{\mathrm{H}}\right)$ has been decreased with increasing the kaolin content in the film, while $\mathrm{H}_{\mathrm{H}}$ has shown higher value because of higher viscosity compared to the $\mathrm{H}_{\mathrm{L}}$ matrix. Presence of kaolin in the film inhibited the erosion process of the film due to the entrapment of kaolin in the HPMC matrix networks. Greater viscosity of $\mathrm{H}_{\mathrm{H}}$ also resulted in more resistance to the film erosion compared to $\mathrm{H}_{\mathrm{L}}$. Increasing diffusion coefficient value indicated that water penetration became faster in presence of kaolin in the film. The calculated value of diffusion coefficient increased with increasing kaolin content in both the matrices. Swelling kinetics of the films with varied kaolin content was investigated by the lag phase sigmoid mathematical model. The predicted swelling content value from the modified lag phase sigmoid model was similar to the observed value. This modified lag phase sigmoid model was successfully fitted to the experimental data, as confirmed by $R^{2}$ and lower RMSE value. The modified Lag phase sigmoid model resulted in $\tau$ values almost equal to the observed $\tau$. Hence, we suggest that the modified version of the lag phase sigmoid model is also reliable enough to calculate kinetics in different food products.

\section{Acknowledgements}

We are very much grateful to the president, Siksha 'O' Anusandhan (Deemed to be University) Prof. (Dr) Manoj Ranjan Nayak for financial support and laboratory facility. Authors are also expressing our gratitude to the Pharmacia and Upjohn Company and Birla Institute of Technology, Mesra, Ranchi, for their gift sample and instrumental facility respectively.

\section{References}

1. A. S. Hoffman, Adv. Drug Deliv. Rev. 2002, 54, 3-12. DOI:10.1016/S0169-409X(01)00239-3

2. N. A. Peppas, K. B. Keys, M. Torres-Lugo, A. M. Lowman, J. Control. Release.1999, 62, 81-87.

DOI:10.1016/S0168-3659(99)00027-9

3. K. Xu, J. Wang, Q. Chen, Y. Yue, W. Zhang, P. Wang, J. Colloid Interf. Sci. 2008, 321, 272-278.

DOI:10.1016/j.jcis.2008.02.024

4. A. Martinez-Ruvalcaba, J. C. Sanchez-Diaz, F. Becerra, L. E. Cruz-Barba, A. Gonzalez-Alvarez, Express Polym. Lett. 2009, 3, 25-32. DOI:10.3144/expresspolymlett.2009.5

5. Y. Tang, J. R. Lu, A. L. Lewis, T. A.Vick, P. W. Stratford, Macromolecules. 2001, 34, 8768-8776.

DOI:10.1021/ma010476i 
6. B. Panda, R. Subhadarsini, S. Mallick, Expert Opin. Drug Del. 2016, 13, 633-643. DOI:10.1517/17425247.2016.1154038

7. S. Pattanaik, S. Nandi, R. N. Sahoo, A. Nanda, R. Swain, S. Das, S. Mallick, Rev. Chim. 2020, 71, 332-345.

DOI:10.37358/RC.20.6.8200

8. R. Mohapatra, S. Senapati, C. Sahoo, S. Mallick, Colloids Surf. B: Biointerfaces, 2014, 123, 170-180.

DOI:10.1016/j.colsurfb.2014.09.012

9. M. Birsan, I. C. Cojocaru, M. I. Stamate, V. Teodor, C. Tuchilus, Rev. Chim. 2016, 67, 1385-1388.

10. N. A. Peppas, A. R. Khare, Adv. Drug Deliv. Rev. 1993, 11, 1-35. DOI:10.1016/0169-409X(93)90025-Y

11. P. Colombo, Adv. Drug Deliv. Rev. 1993, 11, 37-57. DOI:10.1016/0169-409X(93)90026-Z

12. H. Hosseinzadeh, M. Sadeghi, Asian J. Chem. 2012, 24, 85-88.

13. M. Pannirselvam, A. Genovese, M. C. Jollands, S. N. Bhattacharya, R. A. Shanks, Express Polym. Lett. 2008, 2, 429-439. DOI:10.3144/expresspolymlett.2008.52

14. M. Alexandre, P. Dubois, Mat. Sci. Eng. R. 2000, 28, 1-63. DOI:10.1016/S0927-796X(00)00012-7

15. S. S. Ray, M. Bousmina, Prog. Mater. Sci. 2005, 50, 962-1079. DOI:10.1016/j.pmatsci.2005.05.002

16. M. I. Carretero, App. Clay Sci. 2002, 21, 155-163. DOI:10.1016/S0169-1317(01)00085-0

17. E. Cortes-Trivino, I. Martinez, Express Polym. Lett. 2018, 12, 616-627. DOI:10.3144/expresspolymlett.2018.52

18. W. Thakhiew, P. Waisayawan, S. Devahastin, Dry. Technol. 2011, 29, 1396-403.

DOI:10.1080/07373937.2011.588816

19. D. Moreau, C. Chauvet, F. Etienne, F. P. Rannou, L. Corté, Proc Natl Acad Sci. 2016, 113, 13295-13300.

DOI:10.1073/pnas.1609603113

20. M. Gagliardi, Macromol Theor Simul. 2019, 28, 1800063. DOI:10.1002/mats.201800063

21. H. R. Lee, Y. D. Lee, Chem. Eng. Sci. 1991, 46, 1771-1779. DOI:10.1016/0009-2509(91)87023-6

22. T. Tanaka, D. J. Filmore, J. Chem. Phys. 1979, 70, 1214-1218. DOI:10.1063/1.437602

23. Y. Li, T. Tanaka, J. Chem. Phys. 1990, 92, 1365-1371. DOI:10.1063/1.458148

24. C. Wu, C. Yan, Macromol. 1994, 27, 4516-4520. DOI:10.1021/ma00094a013

25. H. J. Schott, Macromol. Sci. B. 1992, 31, 1-9. DOI:10.1080/00222349208215453

26. A. S. Kipcak, O. Ismail, I. Doymaz, S. Piskin, J. Chem. 2014, 2014, 1-9. DOI:10.1155/2014/281063

27. S. H. Othman, N. R. A. Kechik, R. A. Shapi'i, R. A. Talib, I. S. M. A. Tawakkal, J Nanomater, vol. 2019, Article ID 3843949, 12 pages, 2019. DOI:10.1155/2019/3843949

28. Y. Cao, Express Polym. Lett. 2018, 12, 768-780.

DOI:10.3144/expresspolymlett.2018.66

29. M. Grassi, G. Grassi, Curr. Drug Deliv. 2005, 2, 97-116. DOI: $10.2174 / 1567201052772906$
30. P. V. Pramiu, R. L. Rizzi, N. V. Do Prado, S. R. Coelho, P. Z. Bassinello, J. Food Eng. 2015, 165,112-23.

DOI:10.1016/j.jfoodeng.2015.05.020

31. K. G. Kaptso, Y. N. Njintang, A. E. Komnek, J. Hounhouigan, J. Scher, C. M. F. Mbofung, J. Food Eng. 2008, 86, 91-99.

DOI:10.1016/j.jfoodeng.2007.09.014

32. B. C. Marques, L. M. de Matos Jorge, R. M. Jorge, J. Cereal Sci. 2016, 71, 93-98. DOI:10.1016/j.jcs.2016.08.005

33. Lagaly, G., Olphen, H. Van, An Introduction to Clay Colloid Chemistry. Second ed. John Wiley and Sons, New York London, Sydney, Toronto (1977).

34. F. C. H. Pinto, A. Silva-Cunha, G. A. Pianetti, E. Ayres, R. L. Orefice, G. R. Da Silva, J Nanomater. 2011, 2011, Article ID 528628. DOI:10.1155/2011/528628

35. N. A. Peppas, P. Bures, W. Leobandung, H. Ichikawa, Eur. J. Pharm. Biopharm. 2000, 50, 27-46.

DOI:10.1016/S0939-6411(00)00090-4

36. K. G. Kaptso, Y. N. Njintang, A. E. Komnek, J. Hounhouigan, J. Scher, C. M. F. Mbofung, J. Food Eng. 2008, 86, 91-99.

DOI:10.1016/j.jfoodeng.2007.09.014

37. http://www.originlab.com/OriginProLearning.aspx

38. S. Mallick, S. Pattnaik, K. Swain, P. K. De, A. Saha, G. Ghosal, A. Mondal, Eur. J. Pharm. Biopharm. 2008, 68, 346-351. DOI:10.1016/j.ejpb.2007.06.003

39. J. A. Mbey, S. Hoppe, F. Thomas, Carbohyde. Polym. 2012, 88, 213-222. DOI:10.1016/j.carbpol.2011.11.091

40. G. R. Silva, A. Silva-Cunha, F. Behar-Cohen, E. Ayres, R. L. Orefice, Mater. Sci. Eng. C. 2011, 31, 414-422.

DOI:10.1016/j.msec.2010.10.019

41. M. M. Doile, A. K. Fortunato, I. C. Schhücker, S. K. Schucko, M. A. Silva, P. O. Rodrigues, AAPS Pharm. Sci. Tech. 2008, 9, 314-321. DOI:10.1208/s12249-008-9042-Z

42. B. J. Saikia, G. J. Parthasarathy, Mod. Phys. 2010, 1, 206-210. DOI:10.4236/jmp.2010.14031

43. J. Kristo, R. L. Frost, A. Felinger, J. Mink, J. Mol. Struct. 1997, 410-411, 119-122. DOI:10.1016/S0022-2860(96)09488-4

44. F. S. Aleanizy, F. Alqahtani, A. O. Gohary, E. E. Tahir, R. A. Shalabi, Saudi Pharm. J. 2015, 23, 167-176.

DOI:10.1016/j.jsps.2014.06.006

45. R. Mohapatra, S. Mallick, A. Nanda, R. N. Sahoo, A. Pramanik, A. Bose, D. Das, L. Pattnaik, RSC Adv. 2016, 6, 3197631987. DOI:10.1039/C6RA03604J

46. A. Saada, B. Siffert, E. Papirer, J Colloid Interf. Sci.1995, 174, 185-190. DOI:10.1006/jcis.1995.1381

47. A.Ghebaur, S. A. Garea, S.Cecoltan, H. Iovu, Mater. Plast. 2017, 54, 8-13. DOI:10.37358/MP.17.1.4774

48. https://polymerdatabase.com/polymer\%20physics/Solution_ Viscosity.html

49. S. P. Hiremath, N. R. Saha, AAPS Pharm. Sci. Tech. 2008, 9, 1171-1178. DOI:10.1208/s12249-008-9159-0

50. N. A. Peppas, L. Brannon-Peppas, J. Food Eng.1994, 22, 189 210. DOI:10.1016/B978-1-85861-037-5.50015-1 


\section{Povzetek}

Hidracijsko obnašanje polimernega filma na osnovi hidrogela ima velik pomen pri dostavi zdravil v sluznico. Za raziskovanje hidracije filma je bil uporabljen modificirani sigmoidni model na osnovi faznega zamika. Za preučevanje kinetike nabrekanja so bili pripravljeni filmi s kaolinom z vgrajenim HPMC K100LVCR $\left(\mathrm{H}_{\mathrm{L}}\right)$ in K100M $\left(\mathrm{H}_{\mathrm{H}}\right)$, ki so vsebovali deksametazon kot modelno zdravilo. Nabrekanje $\mathrm{H}_{\mathrm{L}}$ in $\mathrm{H}_{\mathrm{H}}$ filmov se je s postopnim povečevanjem vsebnosti kaolina zmanjšalo, $\mathrm{H}_{\mathrm{H}} \mathrm{z}$ višjo viskoznostjo pa je kazal večjo vrednost kot $\mathrm{H}_{\mathrm{L}}$. Kaolin je zaviral tudi postopek erozije filma. Spremenjen matematični sigmoidni model faznega zamika je pokazal podobnost med predvideno in opaženo vsebnostjo nabrekanja. Visoka vrednost $\mathrm{R}^{2}$ in majhna vrednost RMSE sta potrdili uspešno prilagajanje modela eksperimentalnim podatkom za obseg nabrekanja. Tudi dobljena vrednost $\tau$ je bila podobna opaženi. Ta spremenjeni model bi lahko bil dovolj zanesljiv za oceno postopka hidracije v zrnih živil, filmih za pakiranje hrane itd. 